\title{
Verandering van die moreel-etiese situasie in Suid-Afrika in die lig van die kenmotief in 2 Petrus 1:3-4
}

Douw G. Breed

Gereformeerde Kerk Waterkloofrand PRETORIA

E-pos: dbreed@spyda.co.za

\author{
G.J.C. Jordaan \\ Skool vir Bybelwetenskappe en \\ Bybeltale \\ Potchefstroomse Universiteit vir \\ $\mathrm{CHO}$ \\ POTCHEFSTROOM \\ E-pos: ontgjcj@puknet.puk.ac.za
}

\begin{abstract}
The change in the moral-ethical situation in South Africa, in the light of the motif of knowing in 2 Peter 1:3-4

In this article it is argued that in 2 Peter 1:3-4 a motif of knowing is present as a clearly repeated and meaningful semantic unit. An attempt is made to indicate that a profound knowledge ('́t $\left.\iota^{\prime} \gamma \nu \omega \sigma \iota s\right)$ of Jesus Christ was instrumental in giving the apostles accepted religious beliefs ( $\pi i \sigma \tau \iota S)$. These accepted beliefs enabled the apostles to act in such a manner that their behaviour reflected correct religious beliefs and attitudes. The profound knowledge of Jesus Christ also played an important role in the establishment of a covenantal relationship between God and the first readers of 2 Peter. This knowledge also enabled these readers to withstand the moral corruption in the world. In conclusion the possible significance of the motif of knowing in 2 Peter in changing the present South African moral-ethical situation is highlighted.
\end{abstract}

\section{Inleiding}

\subsection{Petrus 1:3-4 en die huidige Suid-Afrikaanse konteks}

In Suid-Afrika is dit duidelik dat dringend aandag gegee moet word aan die morele verval wat in ons land plaasvind. In ' $n$ toespraak tydens 'n spitsberaad oor korrupsie op 10 November 1998 beskryf president 
Thabo Mbeki (Mbeki, 1998) die toestand op daardie stadium as 'n "threatening state of moral degradation of our society" en sê hy dat hierdie toestand "is reflected in the high levels of crime, disrespect for authority and the rule of law, and the erosion of key institutions such as the family". De Wet (1998:10), die redakteur van die dagblad Beeld, skryf in 'n hoofartikel oor die morele verval in Suid-Afrika: “... kerke en nieregeringsinstellings het ' $n$ belangrike rol in die proses om die land se morele vesel te herbou en te verstewig". In dié artikel sê hy ook: "Die beginpunt van die oplossings van talle van Suid-Afrika se knellendste vraagstukke lê in die terugkeer na daardie universele waardes wat die toets van die tyd deurstaan het". Die vraag is egter: wat is hierdie universele waardes waarheen daar teruggekeer moet word en hoe kan daar na hierdie waardes teruggekeer word?

Die bestudering van 2 Petrus 1:3-4 mag moontlik antwoorde gee op hierdie vrae. In dié gedeelte handel die skrywer immers oor gawes wat geskenk is wat tot godsvrug ( $\left.\delta \delta^{\prime} \xi_{\eta}\right)$ lei en oor mense wat die verdorwenheid ( $\phi \theta 0 \rho \hat{s})$ ontvlug het.

\subsection{Die kenmotief in 2 Petrus 1:3-4}

By die lees van 2 Petrus val dit op dat daar dikwels gebruik gemaak word van die woorde $\gamma \nu \hat{\omega} \sigma \iota s(1: 5,6 ; 3: 18)$, émí $\gamma \nu \omega \sigma \iota s \quad(1: 2,3,8 ; 2: 21)$,

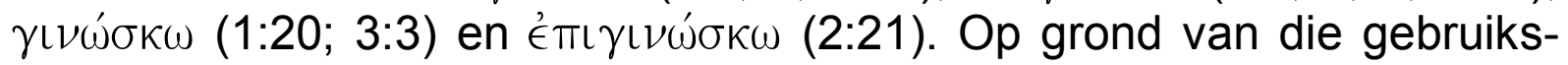
frekwensie van hierdie woorde het verskeie kommentatore tot die gevolgtrekking gekom dat die begrip "kennis" 'n belangrike plek in 2 Petrus inneem (vgl. Bauckham, 1983:170; Fornberg, 1977:12-13; Jordaan, 1988:72-74; Knight, 1995, 58-59).

So belangrik word die plek van die begrip kennis in 2 Petrus geag dat Kahmann (1983:26) en Van Houwelingen (1988:111) na $\gamma \nu \omega \hat{\omega} \sigma \mathrm{\iota s}$ en

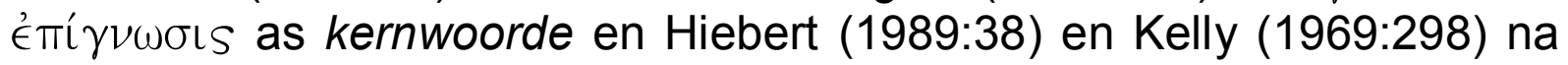

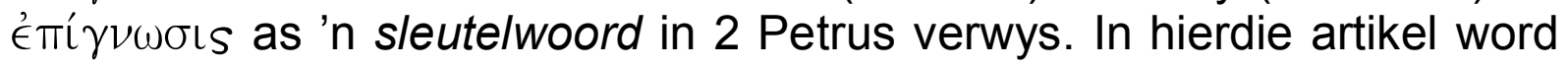
daarom in besonder aandag gegee aan die plek wat die begrip kennis in 2 Petrus 1:3-4 inneem.

Vanuit die studieveld van die semantiek blyk dit dat 'n deeglike studie van die begrip kennis in 2 Petrus 1:3-4 nie beperk kan word tot 'n studie van die woorde $\gamma \nu \hat{\omega} \sigma \iota s / \epsilon ́ \pi i \gamma \nu \omega \sigma \iota s / \gamma \iota \nu \omega \dot{\sigma} \sigma \omega / \hat{\prime} \pi \iota \gamma \iota \nu \omega \dot{\sigma} \sigma \kappa \omega$ nie. Daar moet ook rekening gehou word met woorde wat, binne hulle konteks, in betekenisvelde gebruik word wat met die begrip kennis verband hou (vgl. Louw \& Nida, 1988a:xv-xx). Dit sluit byvoorbeeld die volgende woorde

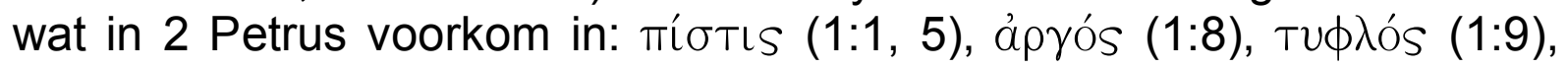

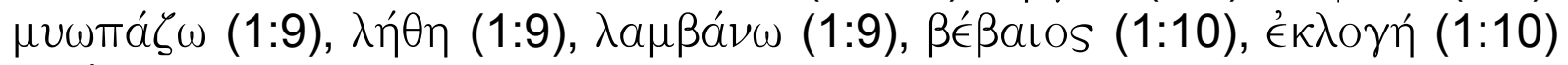

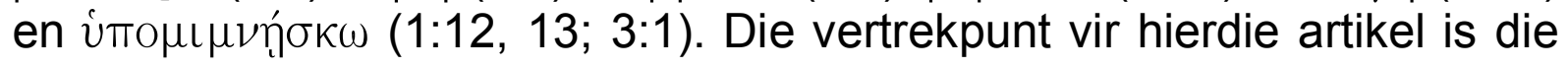


hipotese dat daar in 2 Petrus 'n motief - vir die doeleindes van hierdie artikel die kenmotief - voorkom. Met motief word bedoel 'n herhaalde betekenisvolle element in 'n werk; 'n semantiese eenheid wat ongewysig of met ligte variasies in 'n werk voorkom (vgl. Van Gorp, 1984:202). Daar word aanvaar dat hierdie motief waarneembaar is deur die gebruik van woorde wat met die motief verband hou.

\section{Metodologie}

Hierdie artikel is eksegeties van aard en word gedoen binne die grammaties-historiese model soos dit beoefen is binne die gereformeerde tradisie. Die artikel is gefokus op 'n bepaalde motief (die kenmotief) in 2 Petrus 1:3-11 en die klem val op spesifieke aspekte van 'n eksegetiese metode, te wete die ontleding van die gedagtestruktuur en die bepaling van betekenisse waarvoor Petrus spesifieke woorde gebruik. Ten opsigte van die gedagtestruktuurontleding word aangesluit by die metode van gedagtestruktuurontleding wat deur Coetzee (1988: 19-37) ontwikkel is. Hierdie metode word selfstandig uitgebou deur die relevante resultate van literatuurteoretiese navorsing oor die geskrifte van die Nuwe Testament te verdiskonteer. Daar word veral gefokus op navorsing oor die testamentgenre (vgl. Kolenkow, 1975:57-71 en 1986:259-267; Vögtle, 1972:297-305 en De Jonge, 1991:147-163) en homiletiese stof in die Nuwe Testament (vgl. Baltzer, 1971:97-180; Donfried, 1974:41-48 en Kurz, 1990:16-123). By die definiëring van betekenisse waarvoor Griekse woorde gebruik word, word die diakroniese ontwikkeling van woorde buite rekening gelaat. Barr (1961: 142-145) en Thiselton (1979:80-82) het immers oortuigend aangetoon dat 'n diakroniese studie meer oor die geskiedenis van woorde aan die lig bring as oor die betekenis daarvan. Daar word ook nie uit leksikons en Bybelwoordeboeke 'n opname van "woordbetekenisse" gemaak nie, aangesien skrywers soos Nida en Louw (1992:12-19), Botha (1989a:3) en Silva (1983:44-51) aantoon dat woorde nie oor wortelbetekenisse beskik nie, maar slegs binne gegewe kontekste na betekenisse verwys. Betekenisse word gevolglik gedefinieer volgens die metode van komponensiële analise (vgl. Louw \& Nida, 1988a:vi-xx; Nida, 1972:84-87 \& Botha, 1989b:24-39). Die metode van komponensiële analise word gebruik met die besef dat dié metode inderdaad ook gebreke vertoon (vgl. Breed, 1994:5; Silva, 1983:134-135; Lyons, 1978:333). In navolging van Silva (1983: 132-134) stel Botha (1989b:24-39) 'n betreklik gedetailleerde metode van komponensiële analise aan die hand van Louw en Nida se Leksikon voor. Van Rensburg (1992:291-303) volg 'n soortgelyke metode om "vreemdelingskap" in 1 Petrus te bestudeer (vgl. ook Botha, 1992:43-44). Hierdie gedetailleerde metode van komponensiële analise is vir die doeleindes van hierdie artikel soos volg aangepas: 
- Vanuit die konteks word bepaal of die skrywer die betrokke woord wel in 'n semantiese veld gebruik wat met die kenmotief verband hou.

- Die betekenis waarvoor die woord gebruik word, word gedefinieer deur die volgende stappe te volg:

- Die subdomein waarbinne die woord gebruik word, word bepaal.

- Binne die subdomein word die betekenis waarvoor die woord gebruik word, voorlopig aan die hand van Louw en Nida se definiëring bepaal.

- Die subdomein waarbinne die woord gebruik word, word in die geheelkonteks van omliggende subdomeine geplaas deur dit met daardie subdomeine te kontrasteer.

- Die betekenis waarvoor die woord gebruik word, word gekontrasteer met die omliggende betekenisse binne dieselfde subdomein.

- Uit die voorgaande stappe word 'n uiteindelike definisie van die betekenis waarvoor die woord gebruik word, geformuleer.

Hoewel bostaande metode gevolg is in die studie wat hierdie artikel onderlê, word die stappe slegs ten opsigte van die woorde é $\pi i ́ \gamma \nu \omega \sigma \iota s$ en $\gamma \nu \omega \hat{\omega} \sigma \iota s$ redelik volledig weergegee. Ten opsigte van die ander woorde word slegs die resultate van die definiëring weergegee.

\section{2 Petrus $1: 3-4$ in 'n brief wat tot die testamentgenre behoort}

Stauffer (1948:29-35) het reeds in 1948 die Abschiedreden as Gattung geïdentifiseer en beskryf. Daarna het heelwat studies daaroor gevolg studies deur onder andere Collins (1984:325-355), De Jonge (1991:155163), Kolenkow (1975:57-71) en Kurz (1990:1-130). In die lig van studies wat oor die testamentgenre gedoen is, het onder andere Grundmann (1974:55-56) en Reicke (1982:146) aangetoon dat 2 Petrus ook tot hierdie genre behoort. ' $n$ Belangrike eienskap van die testamentgenre is dat die skrywer van die testament in die skrywe 'n opsomming van sy leer gee. In die Handelinge van Johannes (vgl. Müller, 1974:76-77), wat tot die testamentgenre behoort (Bauckham, 1983:173), word 'n opsomming gevind van die leer van die persoon wat die testament nalaat. Bauckham (1983:173) stel dat daar in hierdie testamente daarna gestreef word "to encapsulate the essence of each teacher's message as he intended it to be remembered after his death". 
Soos in die ander testamentgeskrifte die geval is, gee die apostel Petrus ${ }^{1}$ ook in sy testament ' $n$ opsomming van sy leer, naamlik in 1:3-11. Dat hy wel 1:3-11 as 'n opsomming van sy leer bedoel, blyk daaruit dat hy in 1:12 na hierdie gedeelte terugverwys, wanneer hy sê dat hy sy

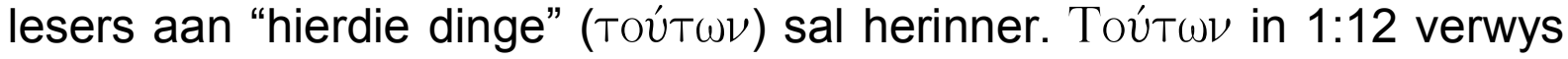
klaarblyklik na 1:3-11.

In hierdie artikel word daarom daarvan uitgegaan dat 2 Petrus 1:3-11 deel is van 'n geskrif wat tot die testamentgenre behoort en dat die apostel in hierdie gedeelte 'n opsomming van sy leer gee.

\section{4. 'n Vaste homiletiese patroon in 2 Petrus en spesifiek in 2 Petrus 1:3-11}

Baltzer (1971:173-175) toon in 'n studie oor The covenant formulary aan dat daar in Joodse en in die vroeë Christelike literatuur 'n vaste homiletiese patroon voorgekom het. Volgens Baltzer se studie bestaan hierdie vaste patroon uit ' $n$ historiese of teologiese gedeelte, 'n etiese aanmoedigingsgedeelte en 'n eskatologiese gedeelte. Baltzer het in sy studie egter nie die Nuwe Testament betrek nie. Donfried (1974:43-48) volg hierdie studie van Baltzer op en toon aan dat hierdie vaste homiletiese patroon ook in die Nuwe Testament voorkom. Hy poog om aan te toon dat 2 Petrus volgens hierdie homiletiese patroon opgebou is. Volgens sy indeling moet 1:3-4 as 'n teologiese gedeelte beskou word en is 1:5-19 'n etiese aanmoedigingsgedeelte en 3:3-13 'n eskatologiese gedeelte. Hy voer aan dat 1:20-3:2 nie tot die oorspronklike dokument behoort nie. Donfried oortuig egter nie. In die gedeelte 1:5-19, wat hy as etiese aanmoedigingsgedeelte aandui, kom 'n gedeelte voor wat as eskatologiese gedeelte geklassifiseer kan word, te wete 1:11. Hoewel 2 Petrus nie in sy geheel volgens hierdie vaste homiletiese patroon gestruktureer is nie, kan met Bauckham (1983:173) saamgestem word dat die skrywer die patroon, wat deur Baltzer aangedui is, wel in 1:3-11 volg. Verse 3-4 is ' $n$ historiese of teologiese uiteensetting en dan volg verse 5-10 met etiese aanmoedigings gerig op die lesers. In 1:11 volg 'n eskatologiese gedeelte. Daar word dus vir die doeleindes van hierdie artikel aanvaar dat daar in die gedagte-eenheid 1:3-11 drie kleiner gedagte-eenhede voorkom wat soos volg uiteengesit kan word:

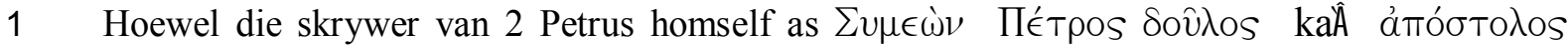

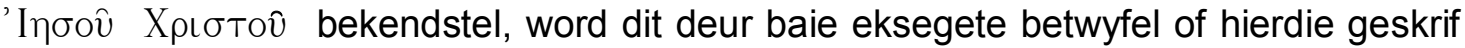
deur die apostel Petrus geskryf is. Breed (1994:11-26) behandel die besware teen die outeurskap van Petrus en maak dit duidelik dat daar nie werklik oortuigend aangetoon kan word dat die brief nie deur die apostel Petrus geskryf is nie. 


\section{1:3-4 Historiese of teologiese gedeelte \\ 1:5-10 Etiese aanmoedigingsgedeelte \\ 1:11 Eskatologiese gedeelte}

In hierdie artikel word slegs aandag gegee aan die historiese gedeelte (v. 3-4) van 2 Petrus 1:3-11. Aangesien dit uit punte 3 en 4 duidelik is dat 2 Petrus 1:3-11 'n hegte eenheid vorm, sou dit belangrik wees dat daar in opvolgstudies aandag gegee word aan die kenmotief in 2 Petrus 1:511.

\section{Wyse van bestudering van die kenmotief in 2 Petrus 1:3-4}

Vir die doel van hierdie artikel is dit belangrik om die kenmotief in 1:3-4 na te gaan; daarom word 'n opname gemaak van woorde in die gedeelte wat volgens Louw en Nida (1988a en b) gebruik word in die semantiese velde wat aan die kenmotief verbind is. Nie alle semantiese velde wat deur Louw en Nida aangedui word, hou met die kenmotief verband nie. Louw en Nida (1988a:349, 380; vgl. ook 1988a:334-346) beskryf die betekenisveld ken (28) in terme van die besit van inligting. Die kenmotief kom dus na vore waar die besit van inligting ter sprake is. Dit blyk egter uit Louw en Nida (1988a:349, 380) dat daar 'n groter groep semantiese velde is wat almal met die besit van inligting verband hou, naamlik:

- Leer (betekenisveld 27), met verwysing na die verkryging van inligting.

- Ken (betekenisveld 28), met verwysing na die besit van inligting.

- Geheue en oproep (betekenisveld 29), met verwysing na die stoor en oproep van inligting.

- Dink (betekenisveld 30), met verwysing na die beheer van inligting.

- 'n Perspektief hê, glo, vertrou (betekenisveld 31), met verwysing na inligting waaroor reeds besluit is.

- Verstaan (betekenisveld 32), met verwysing na die proses waardeur inligting gebruik is om tot die regte begrip en evaluering te kom.

Louw en Nida (1988a:338, 410) toon oortuigend aan dat die semantiese veld kommunikasie (33) wel met inligting verband hou, maar dat die fokus op die kommunikasiegebeure val en nie op die resultaat daarvan nie; daarom word semantiese veld 33 nie beskou as verbandhoudend met die kenmotief nie. Die bestudering van die woorde in 2 Petrus wat met die kenmotief verband hou, word dus beperk tot woorde wat binne semantiese velde 27 tot 32 figureer. Daar word nou aandag gegee aan die kenmotief in die historiese gedeelte (1:3-4) van die apostel se leer. 


\section{Die kenmotief in die historiese gedeelte van die opsomming van die apostel se leer}

Daar word eerstens bepaal watter woorde in die historiese gedeelte die kenmotief dra en tweedens word die plek van hierdie woorde binne die gedagte-eenheid ondersoek.

\subsection{Woorde in die historiese gedeelte waarin die kenmotief na vore tree}

In die historiese gedeelte word twee woorde gebruik wat moontlik die kenmotief dra, te wete die woorde étrí $\gamma \nu \omega \sigma \iota s$ en $\gamma \in \dot{\epsilon} \nu \eta \sigma \theta \epsilon$.

\subsection{1 'E ${ }^{\prime} \gamma \nu \omega \sigma \in \mathrm{l}$}

'Eтí $\nu \omega \omega \in \mathrm{l}$ word in 2 Petrus 1:3 in semantiese veld ken (28) gebruik.2. Volgens Louw en Nida (1988a:334,336) word є́Tí $\gamma \nu \omega \sigma \iota s$ vir betekenisse in die volgende twee van die subdomeine binne semantiese veld 28 gebruik: ken (A) en bekend (B). In subdomein A word є́mi $\gamma \nu \omega \sigma \iota s$ gebruik vir die betekenis om in ' $n$ minder of meerdere mate noukeurige inligting te besit, moontlik met 'n mate van diepgang of bedrewenheid (28.2). In subdomein B word die woord gebruik vir die betekenis die inhoud van dit wat noukeurig bekend is (28.18). Picirilli (1963:35) toon oortuigend aan dat Petrus die woord '́mí $\gamma \nu \omega \sigma \mathrm{s}$ in die brief deurlopend aan 'n persoonlike objek verbind. Daaruit kan afgelei word dat $\epsilon \pi i ́ \gamma \nu \omega \sigma \iota s$ in 1:3 nie verwys na die inhoud van dit wat bekend is nie, maar na die besit van inligting en dus in subdomein A gebruik word. Wanneer die semantiese veld ken (28) met die omliggende semantiese velde leer (27) en geheue en herinner (29) gekontrasteer word, kan afgelei word dat die kennis wat Petrus in vers 2 ter sprake bring, veronderstel dat inligting reeds verkry is. Wanneer die vyf subdomeine waarin die semantiese veld ken (28) verdeel kan word, gekontrasteer word, bring dit geen betekenisvolle inligting na vore vir die nadere definiëring van die betekenis waarvoor die woord in 1:2 gebruik word nie. Die kontrastering van die betekenisse binne die subdomein ken laat blyk dat émí $\gamma \nu \omega \sigma \mathrm{s}$ soos die ander betekenisse in die subdomein, verband hou met die besit van inligting. 'n Onderskeidende betekeniskomponent van '́tí $\gamma \nu \omega \sigma \iota s$ is egter dat die woord gebruik word om inligting wat in 'n mindere of meerdere mate afgebaken is, aan te dui. 'n Verdere onderskeidende betekeniskomponent is dat die woord moontlik 'n mate van diepgang of bedrewenheid veronderstel.

2 In die ander velde waar die woord gebruik word, word dit as deel van idiomatiese uitdrukkings gebruik en Petrus gebruik die woord in 1:3 nie as deel van 'n idiomatiese uitdrukking nie. 
Petrus se gebruik van die woord $\epsilon$ tí $\gamma \nu \omega \sigma$ s elders in die brief dui daarop dat hy met hierdie woord nie slegs die blote besit van inligting wil aandui nie. Uit 1:8 word dit duidelik dat $\hat{\epsilon} \pi \hat{\gamma} \gamma \nu \omega \sigma \mathrm{s}$ afhanklik is van die aard van 'n mens se leefwyse en in 2:20 word beklemtoon dat $\epsilon \pi i \gamma \nu \omega \sigma \iota s$ invloed uitoefen op 'n mens se leefwyse. Op grond van hierdie betekenisnuansering kan afgelei word dat Petrus in 1:3 met die woord $\epsilon$ Ł́ $\gamma \nu \omega \sigma \iota s$ 'n diepgaande besit van kennis wil aandui.

Of hierdie diepgaande besit van kennis dui op die "fundamental saving knowledge" (Bauckham, 1983:170) of op die "decisive knowledge of God which is implied in conversion to christian religion" (Bultmann, 1976:707) of op die "conversion-experience of coming to the knowledge of God and the Lord Jesus" (Picirelli, 1975:93), moet in die lig van Petrus se gebruik van '̇ $\pi i \gamma \nu \omega \sigma l s$ in 1:9 betwyfel word. Uit 1:9 blyk dit dat Petrus vermeer-

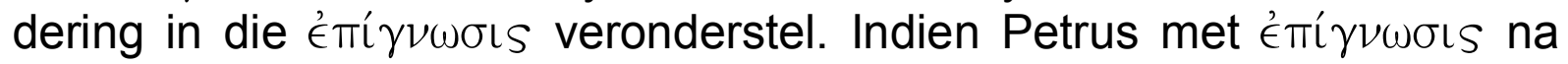
die "fundamental saving knowledge" verwys, sou groei in hierdie kennis nie moontlik wees nie. Petrus verwys dus in 1:3 met émí $\gamma \nu \omega \sigma l s$ na 'n diepgaande besit van kennis wat kan groei en toeneem. Aangesien dit nie oor 'n toename of groei in die hoeveelheid kennis gaan nie, maar oor toename of groei in die besit van kennis, kan die aard van die groei beskou word as 'n groter verdieping of verinniging van die persoonlike verhouding met God en Jesus Christus wat wesenlik deel van die kennis is. Uit die voorgaande afleidings blyk dit dat die kennis wat Petrus in 1:3

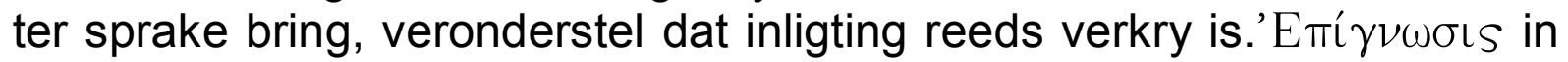
$1: 3$ dui kennis aan wat in 'n mindere of meerdere mate afgebaken is en veronderstel 'n diepgang deurdat ' $n$ innige en persoonlike verhouding bestaan.

Dit blyk dat die betekenis waarvoor die woord $\epsilon$ éi $\gamma \nu \omega \sigma \iota s$ in 1:3 gebruik word, in Afrikaans met diepgaande kennis weergegee kan word.

\subsection{2 Ге́ $\eta \eta \sigma \theta \epsilon$}

Uit Louw en Nida (1988b:51) blyk dit dat uit al die onderskeie velde

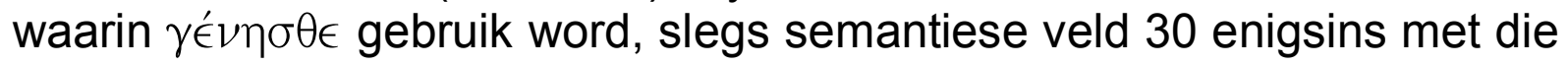
kenmotief verband hou. Louw en Nida (1988b:51) toon aan dat $\gamma \dot{\epsilon} \nu \eta \sigma \theta \epsilon$ in hierdie semantiese veld slegs in 'n idiomatiese uitdrukking gebruik word. Aangesien so 'n idiomatiese uitdrukking hoegenaamd nie in 1:4 ter sprake is nie, is dit duidelik dat $\gamma^{\prime} \in \eta \sigma \theta \epsilon$ in hierdie geval nie met die kenmotief verband hou nie. Daarom kan $\gamma \in \epsilon \eta \eta \sigma \theta \epsilon$ in 1:4 nie as draer van die kenmotief beskou word nie. 


\subsection{Die verband van $\epsilon ́ \pi \iota \gamma \nu \omega ́ \sigma \in \omega S$ met die historiese gedeelte}

Dit is duidelik dat $\dot{\epsilon} \pi \gamma \nu \omega \dot{\sigma} \sigma \omega s$ in 1:3 met verskeie sake in die historiese gedeelte in verband staan. Die verhouding tussen $\dot{\epsilon} \pi \iota \gamma \nu \omega \dot{\sigma} \sigma \omega s$ en hierdie sake word nou nader ondersoek.

\subsection{1 'E godsvrug}

Verse 3-4 bevat die "moeilike" sinsbou van 'n genetivus absolutus (Tท̂S $\theta \in i$ as $\delta v \nu \alpha ́ \mu \epsilon \omega S$... $\delta \in \delta \omega \rho \eta \mu \epsilon \nu \eta S$ ) wat die plek van die hoofsin inneem. Sintakties gesproke, word die handeling van die sin dus deur die genitiewe deelwoord $\delta \in \delta \omega \rho \eta \mu \epsilon ́ \nu \eta s$ gestel, en die subjek van die handeling is

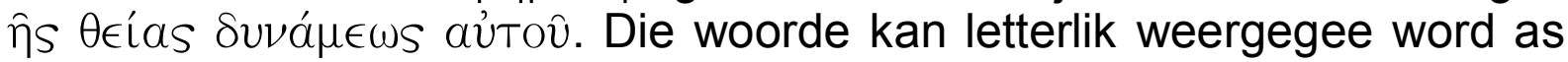
"sy goddelike krag het geskenk". Die handelende persoon is dus eintlik inbegrepe in die subjektiewe genitief aủTov. Dit is egter moeilik om te bepaal na wie Petrus met aủTố in 1:3 verwys. AủTov̂ in 1:3 kan óf na Jesus Christus óf na God die Vader verwys, aangesien albei Persone in die vorige vers vermeld is. Saam met Fornberg (1977:144) en Kahmann (1983:29) kan egter aanvaar word dat Petrus na Jesus Christus verwys, aangesien Jesus Christus in 1:2 laaste vermeld word en derhalwe die naaste antesedent van aủTov is. Die feit dat Jesus Christus reeds in 1:1 God ( $\Theta \epsilon o \hat{)})$ genoem is (vergelyk Breed, 1994:94-95) en daar in 1:3 sprake is van "goddelike krag" (тท̂s $\theta \epsilon i$ as $\delta v \nu a ́ \mu \epsilon \omega s)$, ondersteun die aanname dat aủTố na Jesus Christus verwys. Dit val op dat hierdie frase nie elders in die Nuwe Testament voorkom nie. Hoewel hierdie frase nie deur Nuwe-Testamentiese skrywers gebruik word nie, is die gedagte dat Jesus Christus goddelike krag besit, egter nie vir hulle vreemd nie. In Markus 5:30 praat Markus van die krag wat uit Jesus Christus uitgegaan het. Lane (1975:192) merk oor hierdie woorde van Markus op: "Power is a constitutive element in the biblical concept of the personal God. Jesus possesses the power of God as the representative

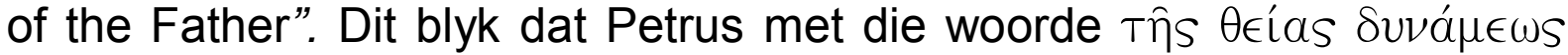
aủTou wil beklemtoon dat Jesus Christus vanuit sy goddelike krag geskenk het.

Die vraag ontstaan na wie Petrus met die woord $i \mu \hat{\imath} \nu$ in 1:3 verwys. Wanneer die volgende argumente in ag geneem word, blyk dit dat met Bigg (1969:253) en Van Houwelingen (1993:31) saamgestem behoort te word dat Petrus met $\hat{\eta} \mu \hat{\imath} \nu$, in onderskeid met die lesers, na die apostels verwys:

- In 1:1 is reeds deur die skrywer 'n onderskeid gemaak tussen die lesers en die apostels toe hy gestel het dat die twee partye, die apostels en die lesers, dieselfde geloof ontvang het (vgl. Breed, 1994: 
95-96). Dit is daarom moontlik dat die skrywer eers oor die een party, die apostels, handel en later oor die ander party, die lesers.

- Die feit dat die skrywer in 1:4 eers stel dat aan "ons" beloftes geskenk is, en dan sê dat daar vir "julle" gevolge is, gee rede om te aanvaar dat Petrus in hierdie verse die onderskeid tussen "ons" en "julle" wil handhaaf. Soos Van Houwelingen (1993:31) tereg stel: "Als de beloften aan alle gelowigen geschonken zijn, dan valt niet goed te verklaren waarom de apostel niet vervolgt met: sodat wij daardoor ...".

- Die afwisseling van die eerste persoon meervoud en tweede persoon meervoud neem 'n prominente plek verder in die brief in. In 1:16 word uitdruklik gestel dat "ons" aan "julle" bekend gemaak het. In dieselfde vers word ook uitdruklik gestel dat "ons", in onderskeid van die lesers, aanskouers was van Jesus se majesteit.

Die persone aan wie daar volgens $1: 3$ geskenk is, is dus Petrus en die ander apostels.

Petrus stel in 1:3 dat die goddelike krag "alles" ( $\pi \alpha ́ \nu T \alpha)$ gegee het. Petrus omskryf nie die "alles" wat aan die apostels geskenk is nie. Die feit dat hy reeds in 1:1 duidelik gemaak het dat die apostels (saam met

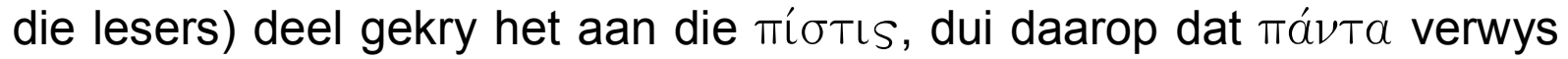

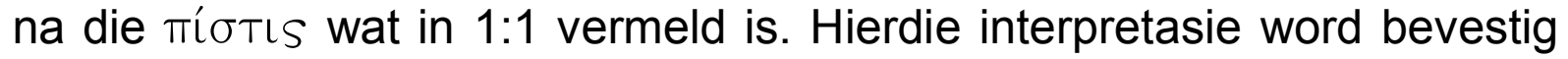
deur die feit dat Petrus in 1:1 beklemtoon dat die mí $\sigma$ TIS deur Goddelike beskikking en keuse verkry is (vgl. Louw en Nida 1988a:128 vir die betekenis waarvoor Petrus die woord $\lambda \alpha_{\chi} 0 \hat{\sigma} \sigma \nu$ in 1:1 gebruik en vgl. ook Breed, 1994:91). Terwyl Petrus in 1:1 die Goddelike betrokkenheid by die verkryging van die geloofswaarhede met die woord $\lambda a x 0 v 0 \sigma \nu$ na vore gebring het, stel hy in 1:3 uitdruklik dat Jesus Christus die geloof ( Die feit dat Petrus die aanhef waarin hy gestel het dat die apostels (en die lesers) die míTTIS deur Goddelike beskikking en keuse verkry het, baie nou verbind aan 1:3-4 (vgl. Kelly, 1969:256 aangaande die gebruik van $\omega$ s in 1:3), dien as verdere ondersteuning van hierdie interpretasie. Dit blyk dat Petrus deur die gebruik van $\omega$ s in 1:3 die saak aangaande

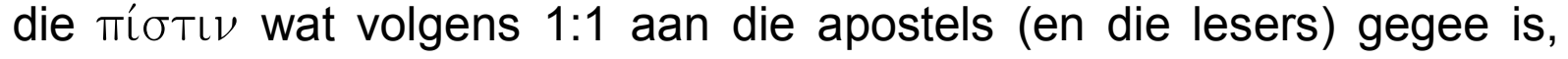
weer hervat. Die "alles" wat aan die apostels geskenk is, is die míoTIS wat in 1:1 ter sprake gebring is. Die feit dat Petrus die woord "alles"

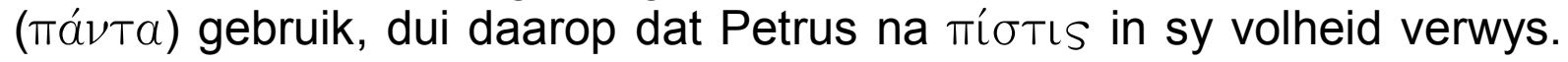

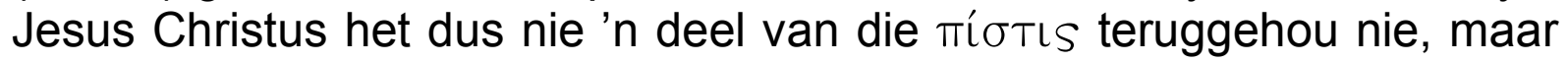
het alles gegee wat nodig is om die doel wat gestel word, te bereik. Uit

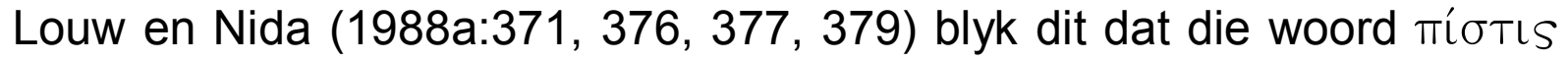
ook moontlik 'n draer van die kenmotief kan wees en dat Petrus dus in

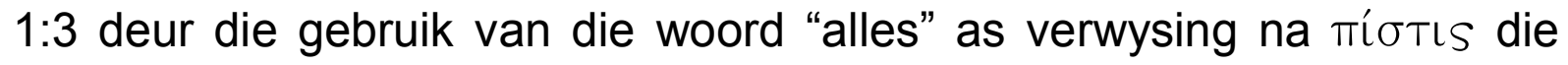


kenmotief na vore bring. Daar word derhalwe nou eers ondersoek gedoen na die betekenis waarvoor die woord tíotıs in 1:1 gebruik word.

Uit verskeie kommentatore se verklaring van die woord míoTIs is dit duidelik dat Petrus die woord míoTls binne die semantiese veld 'n perspektief hê, glo, vertrou aanwend (vgl. Bauckham, 1983:168; Brown, 1980:14; Otto, 1967:234; Schelkle, 1988:185 en Van Houwelingen, 1988:95-96. Vir volledige beredenering, vergelyk Breed, 1994:88). Hierdie semantiese veld, veld 31 , hou met die kenmotief verband. Dit blyk dus dat Petrus die kenmotief deur die gebruik van die woord tíoTIS in 1:5 na vore bring. Louw en Nida (1988a:370, 376-377, 379) dui aan

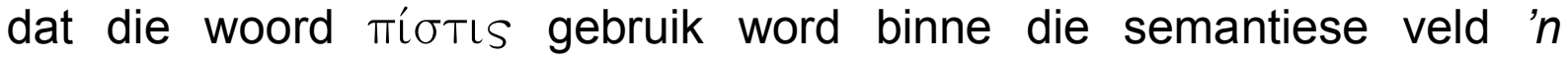
perspektief hê, glo, vertrou (31) in die volgende subdomeine: glo dat iets waar is, (F); vertrou, steun op (I) en 'n gelowige wees, Christelike geloof (J). Bauckham (1983:168) en Van Houwelingen (1988:96) stel dat die geloof waarvan daar in 1:1 sprake is, die fides qua creditur is. Op grond van hierdie siening kan afgelei word dat hulle aanvaar dat die skrywer míOTIS gebruik vir die betekenis wat Louw en Nida (1988a:379) in subdomein $\mathrm{F}$, betekenis 31.102 weergee, te wete om die goeie nuus aangaande Jesus Christus te glo en 'n volgeling te word (31.102). Die volgende feite wys egter daarop dat geloof in 1:1 eerder gesien moet word as die fides quae creditur:

- In 2 Petrus bestry die skrywer 'n valse leer en stel hy die ware leer teenoor die valse leer (vgl. 2 Petrus 1:3-11 en 3:5-13). Dit sou dus logies wees dat Petrus reeds aan die begin van sy skrywe sal handel oor die ware leer waarin die lesers onderrig ontvang het.

- Petrus gee ná die aanhef in 1:3-4 'n kort uiteensetting van dit wat deur hom en die ander apostels geleer is (vgl. punt 3). Dit is waarskynlik dat Petrus daarmee ook die inhoud bespreek van die míoTıs wat die lesers volgens 1:1 ontvang het.

In die lig van bogenoemde moet saam met Knoch (1990:234) aanvaar word dat Petrus nie in 1:1 na die "Glaubenshaltung, dem Akt des Glaubens" verwys nie. Petrus gebruik die woord míoTls in 1:1 dus in subdomein $\mathrm{F}$ vir die betekenis die inhoud van dit wat Christene glo (31.104). Nadat 'n gedetailleerde komponentanalise ${ }^{3}$ van die woord míTis gedoen is, blyk dit dat die woord in 1:1 na 'n stel geloofswaarhede verwys waaroor tot 'n besluit gekom is en wat reeds aanvaar

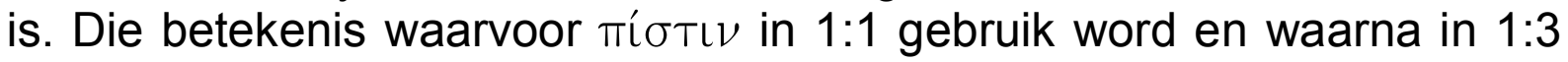

$3 \quad$ Vergelyk Breed (1994:88-91) vir die uiteensetting van hierdie analise. 
verwys word, sou in Afrikaans met aanvaarde geloofswaarhede weergegee kon word.

Petrus stel nie net dat "alles" aan die apostels gegee is nie, maar maak ook duidelik wat die doel is waarom "alles" aan die apostels gegee is. Dit doen hy by wyse van die voorsetsel mpós, gevolg deur twee akkusa-

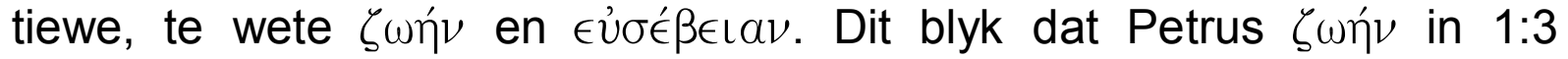
aanwend vir die betekenis ewige lewe of ware lewe (vgl. ook Louw \& Nida, 1988a:261-262) en deur die gebruik van die woord $\epsilon \dot{\sigma} \sigma \epsilon ́ \beta \in \iota \alpha \nu$ beskryf Petrus 'n gedragswyse wat die korrekte geloof en houding uitstraal (vgl. Louw \& Nida, 1988a:532). Die doel waarom "alles" aan die apostels gegee is, is dus eerstens dat dit moet lei tot die ewige lewe en tweedens dat daaruit 'n gedragswyse na vore moet tree wat die korrekte geloof en houding uitstraal. Wanneer daarop gelet word dat Petrus die woord $\pi \alpha ́ \nu T \alpha$ emfaties aan die begin van die sin plaas, is dit duidelik dat hy wil beklemtoon dat Jesus Christus se Goddelike krag nie onvolledig gegee het nie, maar dat álles gegee is. Dit wat die apostels ontvang het, dien volledig daartoe dat die ewige lewe ontvang is en dat dit moontlik is om volgens God se wil te lewe. Dit is opmerklik hoe die skrywer Goddelike krag en menslike verantwoordelikheid met mekaar in verhouding bring. Goddelike krag is aan die apostels gegee, maar dit wat gegee is, moet daartoe dien dat volgens God se wil gelewe word. Petrus maak dit dus duidelik dat Jesus Christus met sy Goddelike krag in 'n besondere vennootskapsverhouding met die dissipels te staan gekom het. Die gawe wat Hy deur sy Ggoddelike krag aan hulle gegee het, word vir hulle 'n opdrag om volgens God se wil te lewe.

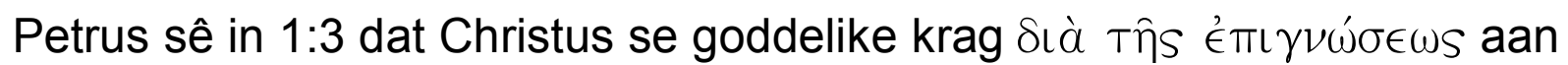
die apostels alles geskenk het. Hy stel $\epsilon \operatorname{tr} \gamma \nu \omega \dot{\sigma} \sigma \epsilon \omega$ daarmee as die instrument waarmee $\pi \alpha ́ \nu T \alpha$ aan die apostels geskenk is (Greijdanus, 1929:242; Kelly, 1969:300; Grundmann, 1974:69). Jesus Christus het dus die diepgaande kennis as instrument gebruik om aan die apostels alles te gee wat dien tot die ewige lewe en tot 'n leefwyse volgens God se wil.

\subsection{2 'E}

Die skrywer stel uitdruklik Wie die objek van die kennis is, te wete tov

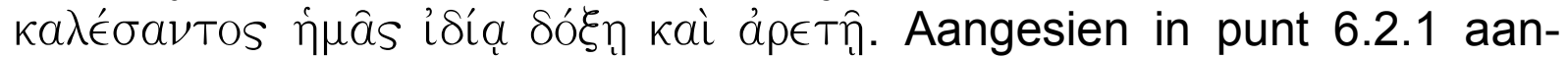
vaar is dat $\hat{\eta} \mu \hat{\imath} \nu$ in 1:3a na die apostels in onderskeid van die lesers verwys, is dit ook logies om te aanvaar dat $\eta \mu \hat{\alpha}$ in $1: 3 b$ na die apostels verwys en nie na alle gelowiges nie. Wanneer aanvaar word dat dié wat geroep is die apostels is, kan ook aanvaar word dat die Een wat die apostels geroep het, Jesus Christus is. Die aanname dat dit Christus is wat geroep het, is geldig aangesien die roeping van die apostels deur 
Jesus Christus 'n baie besondere plek in die vroeg-Christelike kerk ingeneem het (vgl. byvoorbeeld Mark. 1:16-20). Petrus vermeld ook nog die instrumente waarmee Jesus Christus die apostels geroep het, te wete met sy $\delta o ́ \xi \eta ̣$ en $\alpha \rho \in T \hat{\text {. }}$. Dit wat die apostel in 1:16 skryf, bevestig dat

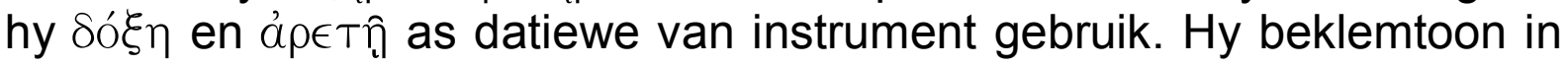
1:16-18 dat hyself en die ander twee apostels aanskouers was van Jesus Christus se heerlikheid. Hulle het sy $\mu \in \gamma a \lambda \circ \pi \rho \in \pi \circ \hat{s}$ aanskou

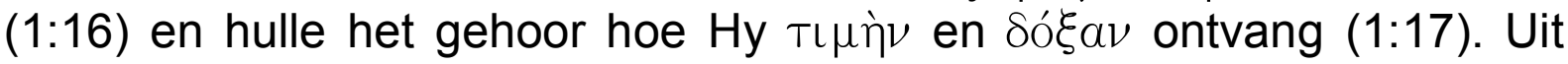
$1: 16-18$ is dit duidelik dat dit wat hulle gesien en gehoor het, as begronding gedien het vir die dinge wat hulle aan die lesers bekendgemaak het. Hulle het dit as roeping beskou om die betekenis van die dinge wat hulle gesien en gehoor het, aan die lesers te verkondig. Die roeping waarna Petrus in 1:3 verwys, het dus spesifiek betrekking op die roeping van die apostels om aan die lesers bekend te maak wat die dinge beteken wat hulle tydens die verheerliking aanskou en gehoor het. Dit word duidelik dat die diepgaande kennis waarna Petrus in 1:3 verwys, kennis is wat impliseer dat Jesus Christus geken word as die Een wat geroep het om die betekenis van dit wat tydens die verheerliking aanskou en gehoor is, te verkondig.

\subsection{3 ${ }^{~} E \pi\llcorner\gamma \nu \omega ́ \sigma \in \omega s$ en die Persoon wat die beloftes gegee het}

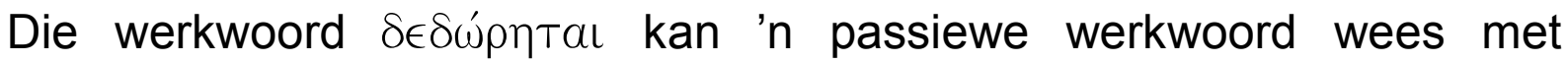
$\epsilon \in \pi \gamma \gamma \hat{\epsilon} \lambda \mu \alpha \tau \alpha$ as die subjek. Die werkwoord kan egter ook as medium verstaan word. Die feit dat $\delta \in \delta \omega \rho \eta \mu \epsilon ́ \nu \eta s$ in 1:3 in die medium staan, toon

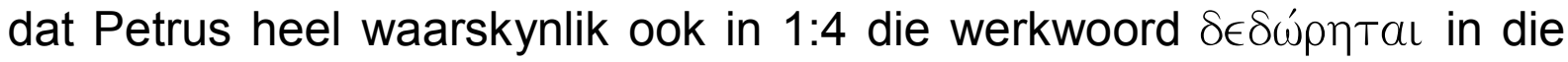

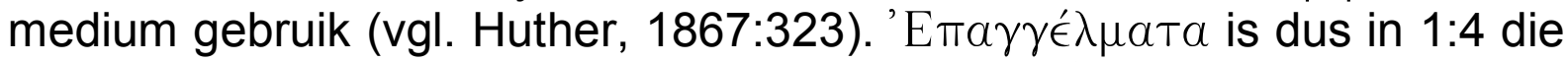

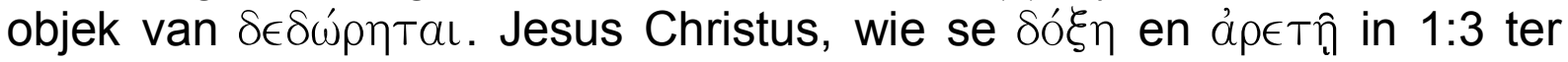
sprake was, is die subjek. Jesus Christus is die Een wat gegee het en

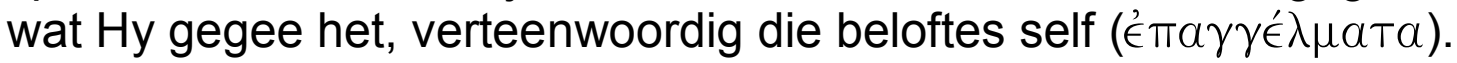

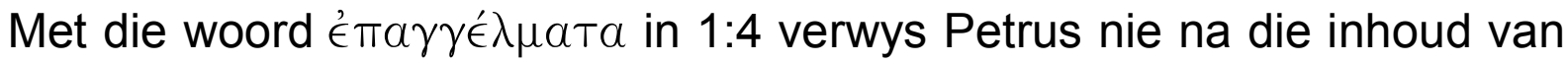
beloftes wat reeds ontvang is nie, maar na beloftes wat gemaak is en waarvan die inhoud nog in die toekoms ontvang moet word. Dit word

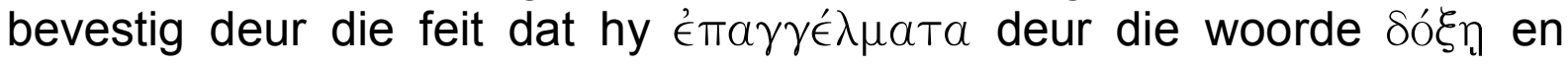
$a j \rho \in \pm$ kwalifiseer, asook die feit dat hy verder aan in die brief, in 1:11 en weer in 3:13, toekomstige gebeure wat heerlike gevolge vir sy lesers inhou, aan die orde stel. Petrus maak dit dus duidelik dat Jesus Christus die grootste en kosbare beloftes vir die toekoms gegee het. Diegene aan wie die beloftes geskenk is, word in die datief gestel, te wete $\eta \mu \hat{\imath} \nu$ (1:4). Hulle is dieselfde mense as die $\hat{\eta} \mu \hat{\imath} \nu$ van $1: 3$, te wete die apostels (vgl. punt 7.2.1).

Petrus dui met $\delta \iota ! \hat{\omega} \nu 1: 4$ die instrumente aan waarmee Jesus Christus aan die apostels die beloftes gee. Daar kan aanvaar word dat die 


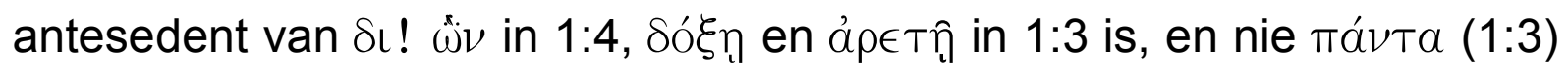

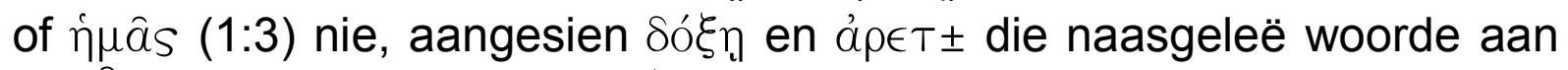

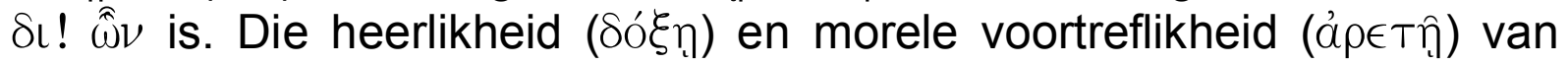
Jesus Christus is dus die instrumente waarmee Jesus Christus die beloftes aan die apostels geskenk het.

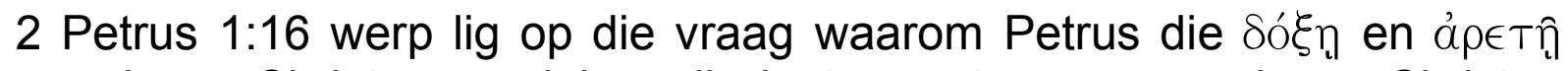
van Jesus Christus aandui as die instrumente waarmee Jesus Christus beloftes aan die apostels geskenk het. Petrus beklemtoon immers in 1:16 dat hy en die ander twee apostels tydens die verheerliking Jesus Christus se $\mu \in \gamma a \lambda \in i o ́ T \eta T o s$ aanskou het $(1: 16)$ en dat hulle gehoor het hoe Hy $\tau \iota \mu \eta v \nu$ en $\delta o ́ \xi \alpha \nu$ ontvang het (1:17). Dit wat die apostels van Jesus Christus gesien en gehoor het, het aan hulle duidelik gemaak wat in die toekoms gaan gebeur. Op grond van hierdie openbaring kon die apostels ook aan die lesers die dinge aangaande die kragtige koms van Jesus Christus bekend maak. In ooreenstemming hiermee dui Petrus in 1:4 Christus se $\delta o ́ \xi \eta ̣$ en $\alpha \hat{\rho} \in T \hat{\text { a }}$ as die instrumente aan waarmee Hy die beloftes aan die apostels gegee het. Deur die openbaring van sy heerlikheid en deug het $\mathrm{Hy}$ aan hulle die kosbare en allergrootste beloftes van sy kragtige koms gegee. In 1:3-4 word die volgende omgekeerde parallelisme aangetref wat verdere lig werp op die heerlikheid en deug as instrumente waardeur die beloftes geskenk is:

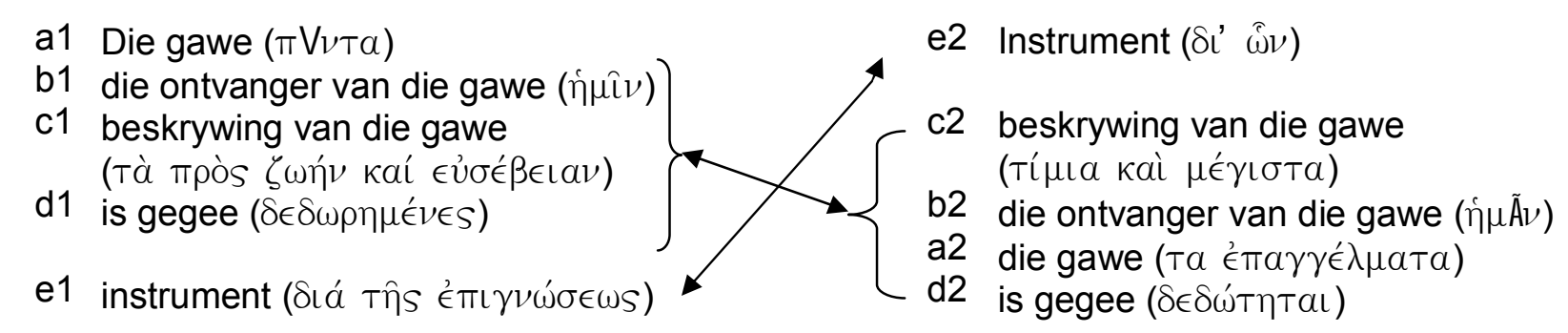

Die omgekeerde parallelisme bestaan uit twee bene waarin die gawe wat gegee is, die ontvanger van die gawe, die beskrywing van die gawe en die instrument waardeur gegee is as 't ware soos 'n spieëlbeeld gerangskik is. Sodoende word die instrument waardeur die gawe gegee word, in albei gevalle sentraal gestel. Hierdie wyse van strukturering het belangrike implikasies vir die manier waarop die kenmotief in hierdie verse figureer. Die instrument waardeur die gawe gegee word, hou immers in albei gevalle direk verband met $\epsilon \pi i \gamma \nu \omega \sigma \iota s$. In die eerste been van die parallelisme (a1-e1) is die instrument duidelik diepgaande kennis van Hom wat ons geroep het deur sy heerlikheid en deug (e1). In die tweede been van die parallelisme (a2-e2) word die instrument gestel deur die relatiewe frase $\delta \iota ! \hat{\omega} \nu(\mathrm{e} 2)$. Die antesedent van die relatiewe sin

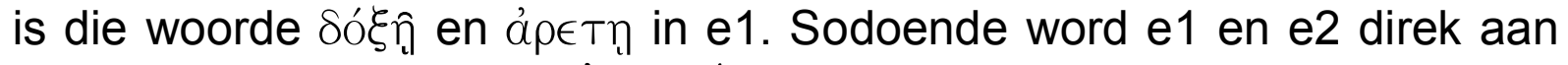

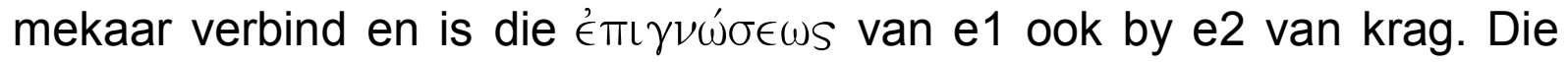


diepgaande kennis waardeur Christus sy gawes gee, is dus nie net kennis van Jesus as die Een wat deur sy heerlikheid en deug sy apostels geroep het nie (e1), maar ook kennis van Hom as die Een wat deur daardie selfde heerlikheid en deug beloftes aan die apostels gemaak het (e2-d2). Die instrument waardeur Christus sy beloftes aan die apostels geskenk het, is dus $\dot{\epsilon} \pi \iota \gamma \nu \omega \dot{\sigma} \sigma \hat{\omega} s$ - diepgaande kennis aangaande Jesus Christus as die Een wat deur sy heerlikheid en deug sy apostels geroep het en aan hulle beloftes gemaak het.

\subsection{4 'Emí $\gamma \nu \omega \sigma \epsilon \omega s$ en dit wat die lesers volgens 1:4b sal wees ( $\gamma \in \dot{\epsilon} \nu \eta \theta \epsilon)$}

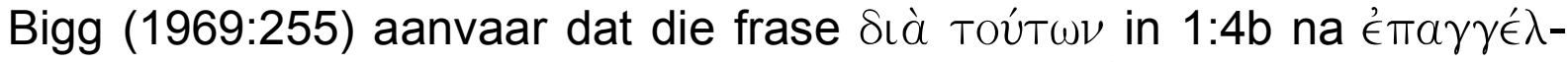

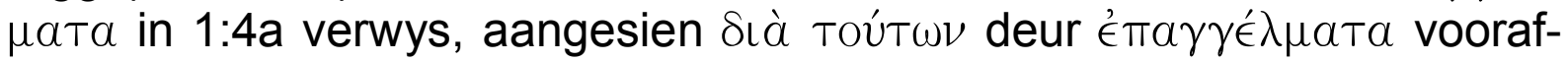
gegaan word. In die vorige punt is egter aangetoon dat die beloftes

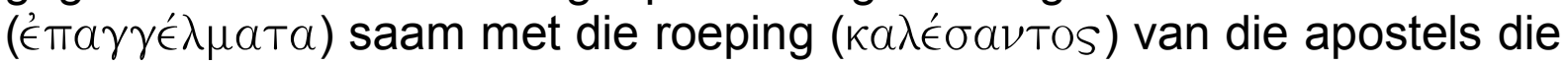
inhoud is van die diepgaande kennis ( $\epsilon \pi \iota \gamma \nu \omega \dot{\omega} \sigma \in \omega S)$ wat in 1:3 vermeld word. Hierdie diepgaande kennis dien volgens 1:3 weer as die instrument waarmee Jesus Christus aan die apostels die volledige geloofswaarhede gee (vgl. punt 6.2.1). In die lig daarvan dat 1:3-4a so 'n hegte eenheid vorm, blyk dit beter te wees om te aanvaar dat Petrus met

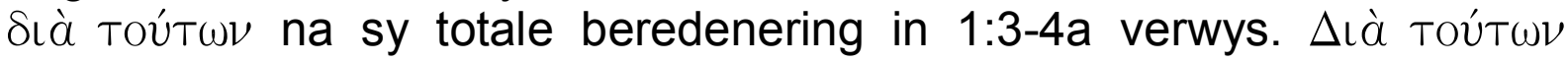
verwys dus eerstens na die feit dat Jesus Christus aan die apostels al die geloofswaarhede gegee het wat dien tot die ewige lewe en tot 'n leefwyse volgens God se wil. $\Delta \mathrm{l} \grave{\alpha}$ Toút $\omega \nu$ verwys egter tweedens ook na die wyse waarop Jesus Christus aan die apostels al die geloofswaarhede gegee het. Hy het die geloofswaarhede naamlik deur die diepgaande kennis van Jesus Christus gegee - Jesus Christus wat die apostels geroep het en aan hulle beloftes gegee het. Die demonstratief

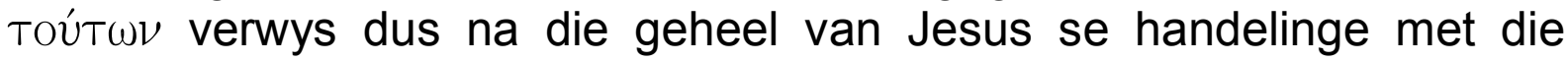
apostels soos dit in 1:3-4a beskrywe is. Die voorsetsel Sid̀ verbind dit instrumenteel aan 1:4b: deur al daardie handelinge van Jesus met sy apostels het Hy iets anders bewerk. Daardie iets anders stel Petrus by wyse van iva plus die konjunktief.

Van Houwelingen (1988:101) is oortuig dat i $i \alpha$ saam met die konjunktief

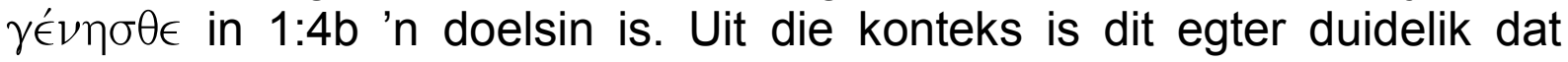

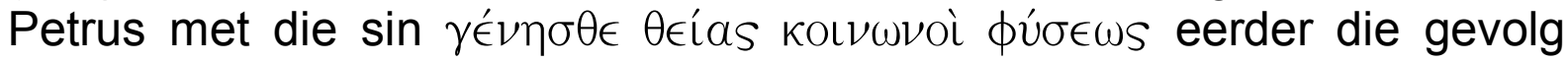

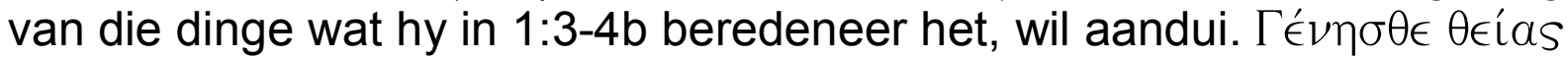

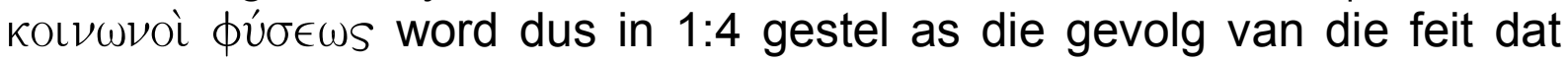
Jesus Christus aan die apostels al die geloofswaarhede gegee het en dat Hy dit gegee het deur die kennis van Hom wat hulle geroep en aan hulle die beloftes gegee het. 
Die oorgang vanaf die eerste persoon "ons" in 1:3-4a na die tweede persoon "julle" in 1:4b is baie opvallend. Van Houwelingen (1993:31) wys daarop dat hierdie oorgang "extra geaccentueerd" word deur die verskil in werkwoordsvorm (vanaf perfektum na aoristus). Dit is duidelik dat Petrus, nadat hy in 1:3-4a gestel het wat aan die apostels gegee is, wil duidelik maak watter gevolge dit vir die lesers inhou dat hierdie dinge aan die apostels gegee is.

Die vraag is egter waarom dit vir die lesers gevolge inhou wanneer Jesus Christus aan die apostels sekere dinge gee. Die feit dat Petrus in 1:3 beklemtoon dat Jesus Christus besondere kennis as instrument gebruik om aan die apostels alles te gee, verskaf die antwoord op hierdie vraag. Hierdie kennis waardeur Jesus Christus aan die apostels alles gee, hou in dat die apostels Jesus Christus ken as die een wat hulle geroep het om die betekenis van dit wat hulle tydens die verheerliking aanskou en gehoor het, te verkondig (vgl. punt 6.2.2). Die apostels se roeping het dus die opdrag tot bekendmaking ingehou. Uit 1:16 blyk dit dat die apostels hierdie opdrag uitgevoer het en het dit, soos blyk uit die gebruik van ǐva saam met die konjunktief $\gamma^{\prime} \nu \eta \sigma \theta \epsilon$ in $1: 4$, vir die lesers gevolge ingehou. Omdat die apostels dus die geloofswaarhede wat hulle ontvang het, aan die lesers verkondig het, het dit wat hulle ontvang het, vir die lesers gevolge ingehou.

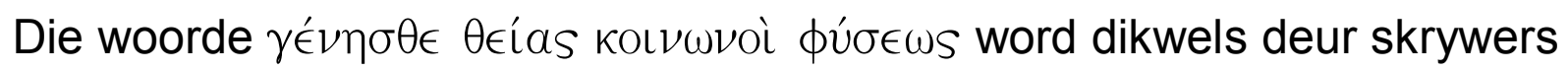
verstaan teen die agtergrond van die Hellenistiese filosofie. Frankemölle (1990:92), Kahmann (1983:31-33), Kelly (1969:303), Knoch (1990: 239240) en Paulsen (1992:108-110) aanvaar in die lig van die Hellenistiese filosofie dat die skrywer met hierdie woorde aan sy lesers voorhou dat die mens op een of ander wyse deel kry aan God, spesifiek aan die onsterflikheid van die Godheid. Wolters (1990:28-44) dui egter aan dat

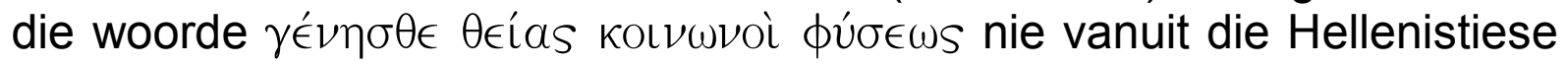
filosofie verklaar moet word nie, maar dat dit verbondsmatig verstaan moet word 4 . Hy bevestig sy standpunt deur te wys op die betekenisse

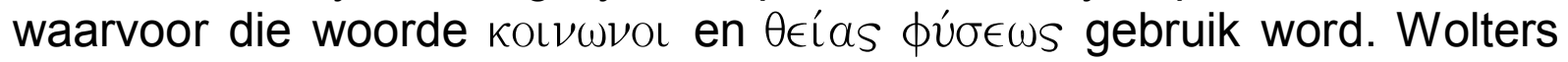

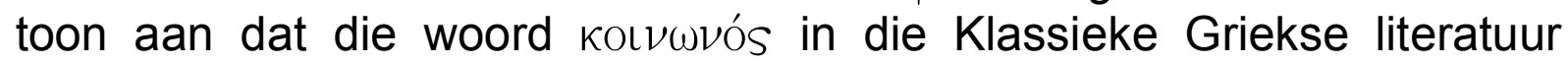
normaalweg na die betekenis "vennoot" ("partner") verwys 5 . Hy wys ook

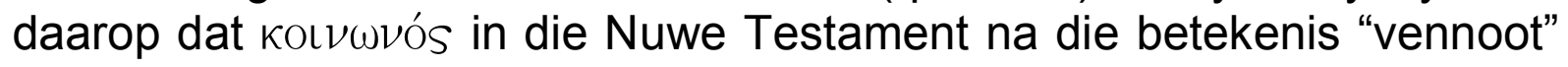
verwys. Uitsonderings is egter 2 Korintiërs 1:7 en 1 Petrus 5:1 (waar

$4 \quad$ Van Houweling (1993:34) poog om aan te toon dat hierdie interpretasie van Wolters nie geldig is nie. Van Houweling se besware teen Wolters se teorie is deur Breed (1994:121-122) uiteengesit.

5 Vergelyk ook Louw en Nida (1988b:144 en 1988a:447) vir die betekenis waarvoor die woord

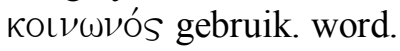




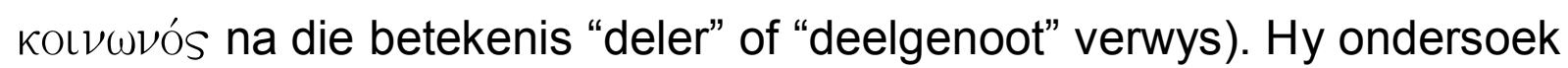
ook nie-literêre papiri en bevind dat dié woord bykans sonder uitsondering verwys na die betekenis "vennoot", en in die besonder "besigheidsvennoot". Wolters (1990:33-34) sê verder:

When associated with a genitive case, the general rule appears to be that Kolv $\omega \nu$ OS means 'partner' when the noun in the genitive refers to a person but that it means 'partaker' when the noun in the genitive refers to a thing.

Hy toon daarna oortuigend aan dat $\theta \in i$ as $\phi u ́ \sigma \epsilon \omega S$ 'n goddelike persoon of God verteenwoordig en dat in 1:4 dus as "partner" vertaal moet word. Volgens hierdie interpretasie handel Petrus dus nie in 1:4b oor deelgenote aan die goddelike natuur nie, maar oor vennote van God. Hierdie vennootskapsverhouding, so toon Wolters aan, is niks anders as die verbondsverhouding tussen God en die gelowiges wat telkens deur ander Bybelskrywers na vore gebring word nie. Die feit dat Petrus in die res van die brief baie Hellenistiese terme gebruik (vgl. Breed, 1994:30 en Danker, 1978:64-82), laat blyk dat dit nie eienaardig is dat Petrus hierdie verbondsverhouding, soos ook ander sake in die brief, in Hellenistiese terme weergee nie. Die duidelike parallel tussen dit wat Petrus in 1:3-4a aangaande die apostels sê en dit wat hy in 1:4b aangaande die lesers sê, bevestig Wolters se teorie. Petrus het immers reeds in 1:3 oor 'n vennootskap tussen Jesus Christus en die apostels gehandel (vergelyk punt 6.2.1). Jesus Christus se goddelike ( $\theta \in i$ ias) krag het volgens 1:3 aan die apostels alles gegee en dit lei tot 'n leefwyse volgens God se wil. Wanneer die lesers in 'n vennootskapsverhouding ( $\phi \dot{\sigma} \sigma \in \omega s$ ) met die Godheid ( $\theta \in i$ as $\phi u ́ \sigma \in \omega S$ ) te staan kom, behoort dit ook volgens 1:5 tot 'n spesifieke leefwyse te lei (let op кaì aủTò тоûTo $\delta \epsilon ́$ in 1:5). Die parallel tussen 1:3-4a en dit wat Petrus vanaf 1:4b en verder stel, strek egter nog verder. Nadat Petrus in 1:3 verklaar het dat die Goddelike krag alles

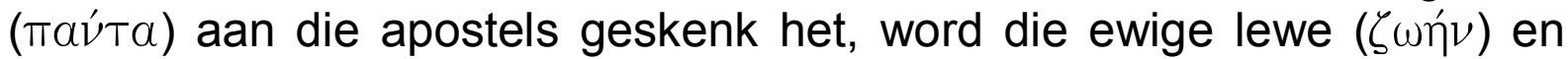

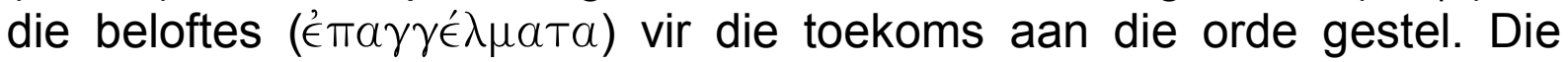
skrywer volg dieselfde redevoeringspatroon wanneer hy in 1:4 oor die verhouding tussen die lesers en God handel en dan, nadat hy in 1:5-10 die leefwyse van die lesers verbesonder het, word die ewige lewe van die lesers in 1:11 aan die orde gestel.

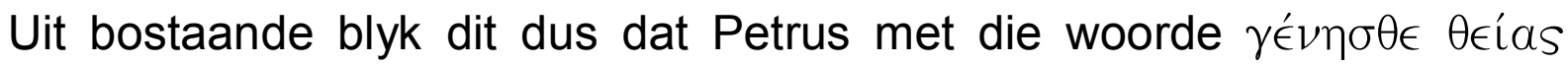

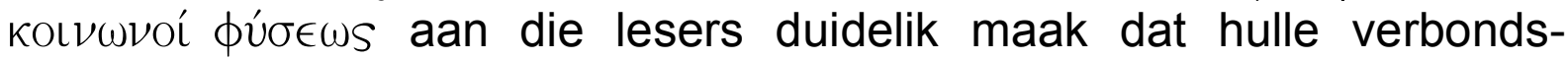

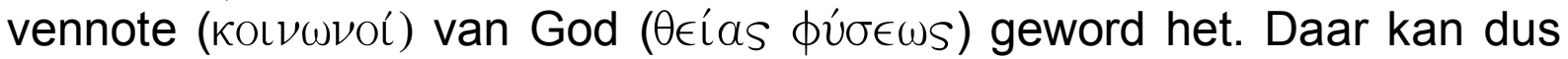
aanvaar word dat Petrus, nadat hy in 1:3-4a duidelik gemaak het wat Jesus Christus aan die apostels gegee het en hoe Hy dit aan hulle gegee het, in 1:4b die gevolge daarvan vir die lesers duidelik maak. Die 
lesers het as gevolg daarvan in 'n verbondsverhouding met God te staan gekom.

Nadat Petrus die verbondsverhouding waarin die lesers met God te staan gekom het, geteken het, stel hy by wyse van 'n deelwoordfrase die

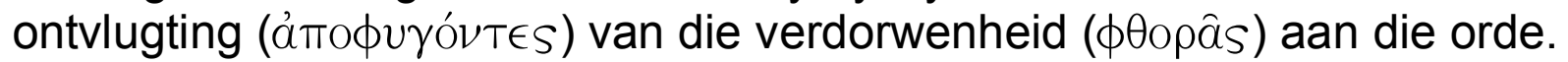

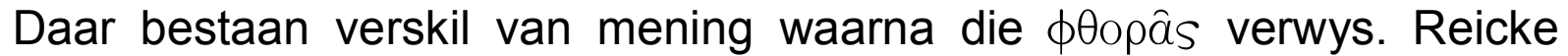
(1982:152-153) is oortuig dat dit na morele verdorwenheid verwys. Daarteenoor stel Bauckham (1983:182-183), Kelly (1969:302-304) en Van Houwelingen (1993:33) dat dit verwys na die fisieke verweer van die mens. Die feit dat die fisieke verderf nie werklik in die brief ter sprake kom nie, terwyl die morele verdorwenheid duidelik ter sprake is (vgl.

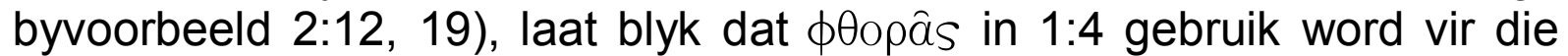
betekenis morele verderf en agteruitgang (vgl. Louw \& Nida, 1988a:771).

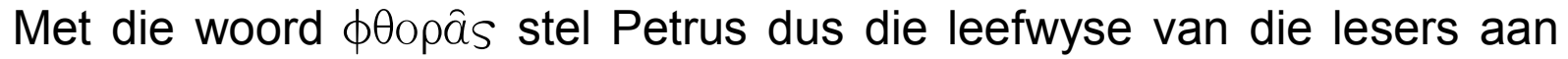
die orde, naamlik 'n leefwyse waarin hulle morele verdorwenheid ontvlug het. Volgens Bauckham (1983:182) dui die gebruik van die aoristus

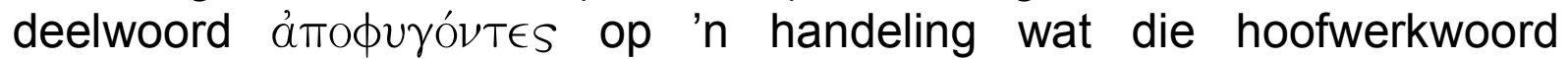
$\gamma \in \mathcal{\prime} \nu \eta \sigma \theta \epsilon$ voorafgaan. In die lig daarvan dat die aoristus deelwoord gewoonlik 'n voorafgaande handeling uitdruk, blyk hierdie interpretasie 'n sterk moontlikheid te wees. Dit is egter meer waarskynlik dat die aoristus deelwoord in hierdie geval ingressief gebruik word. Ter motivering hiervan dien die volgende: in 1:3 het Petrus duidelik gemaak dat dit wat die apostels ontvang het, tot 'n leefwyse volgens God se wil lei. Wanneer Petrus dan in 1:4b oor die lesers handel, maak hy duidelik dat die verbondsverhouding waarin hulle met God staan, daartoe lei dat hulle begin het om die morele verdorwenheid te ontvlug. Dit kan daarom

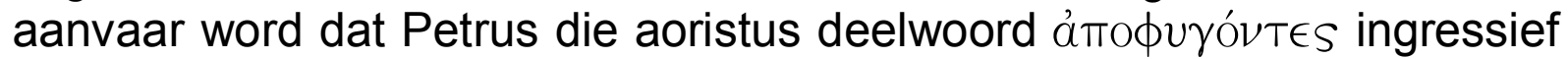
gebruik.

Dit word uit die voorgaande gegewens duidelik dat die apostels se diepgaande kennis ' $n$ belangrike plek inneem in die totstandkoming van die verbondsverhouding tussen die lesers en God, asook in die lesers se ontvlugting van die morele verdorwenheid. Die diepgaande kennis was die instrument waardeur Jesus Christus aan die apostels alles gegee het wat tot die ewige lewe en tot 'n lewe volgens die wil van God lei. Hierdie kennis het behels dat Jesus Christus geken word as die Een wat geroep het om dit wat tydens die verheerliking waargeneem is, bekend te maak. As gevolg van hierdie bekendmaking het die lesers in 'n verbondsverhouding met God te staan gekom en het dit daartoe gelei dat die lesers begin het om die morele verdorwenheid te ontvlug. 


\section{Die betekenis van die kenmotief in 1:3-4 vir die huidige Suid-Afrikaanse konteks}

In Suid-Afrika, 'n land waar die president verwys na die "threatening state of moral degradation of our society" (vgl. punt 1.1) kan die verkondiging van die aanvaarde geloofswaarhede waarna Petrus in 1:3-4 verwys, 'n groot verskil maak. Dit is immers uit Petrus se getuienis duidelik dat hierdie geloofswaarhede mense se lewens werklik verander. Die apostels is deur hierdie geloofswaarhede in staat gestel om 'n gedragswyse te volg wat 'n korrekte geloof en houding uitstraal - hulle kon volgens God se wil lewe (vgl. punt 7.2.1). Ook Petrus se lesers se lewe het verander nadat hierdie geloofswaarhede aan hulle verkondig is. Hulle het begin om die morele verdorwenheid te ontvlug (vgl. punt 7.2.4). Terwyl daar in Suid-Afrika groot magteloosheid ervaar word aangesien die sedelike verval, ondanks alle pogings om dit te stuit, steeds toeneem, bied die verkondiging van hierdie geloofswaarhede aan die inwoners van hierdie land werklike hoop. Kerke in Suid-Afrika behoort ernstig te besin of die ywer waarmee hulle die geloofswaarhede van die Skrif in hierdie land verkondig, hierdie hoop weerspieël.

- Wie hierdie geloofswaarhede verkondig, moet egter begryp dat kennis van Jesus Christus die instrument is waardeur hierdie aanvaarde geloofswaarhede aan iemand geskenk word (vgl. punt 6.2.3). Hierdie kennis behels dat ' $n$ persoon in ' $n$ innige persoonlike verhouding met Jesus Christus moet staan - 'n verhouding waarin Jesus Christus geken word as die Een wat sy apostels deur sy heerlikheid en deug geroep het (vgl. punt 6.2.4) en deur daardie selfde heerlikheid en deug aan hulle die grootste en kosbare beloftes vir die toekoms gegee het (vgl. punt 6.2.3). Wanneer hierdie geloofswaarhede verkondig word, moet daar dus gewaak word om nie maar slegs inligting te probeer oordra nie. Die persoon aan wie verkondig word, moet gelei word tot ' $n$ innige persoonlike verhouding met Jesus Christus.

- Uit die bestudeerde gedeelte is dit duidelik dat die verantwoordelikheid van die mens wat die geloofswaarhede aanvaar het, sterk beklemtoon moet word. Petrus sê dat die apostels, wat al die geloofswaarhede ontvang het, die verantwoordelikheid gehad het om volgens God se wil te lewe. Die gawe wat hulle ontvang het, het vir hulle 'n opdrag geword om volgens God se wil te lewe (vgl. punt 6.2.1). Die verantwoordelikheid van die mens wat die geloofswaarhede aanvaar het, word ook deur Petrus beklemtoon wanneer hy duidelik maak dat die lesers se lewe nie dieselfde gebly het nadat die geloofswaarhede aan hulle verkondig is en hulle in 'n verbondsverhouding met God te staan gekom het nie. Hulle het begin om die morele verdorwenheid te ontvlug (vgl. punt 6.2.4). Die beklemtoning van die mens se 
verantwoordelikheid is in besonder vir die gelowiges in Suid-Afrika van groot belang. Omdat die morele verval in Suid-Afrika sulke groot afmetings aanneem, is die versoeking vir gelowiges groot om korrupsie, sedeloosheid en opstand teen gesag te aanvaar en selfs daaraan deel te hê. Wanneer gelowiges egter leef vanuit die besef van hulle verbondsverhouding met God en hulle verantwoordelikheid teenoor Hom met wie hulle in so 'n besondere verhouding staan, sal hulle ook soos die lesers die morele verval en agteruitgang ontvlug. Vanuit hulle verhouding met God sal hulle hulle lewe volgens God se wil inrig.

- Hoewel die verkondiging van die geloofswaarhede van groot belang is vir die teëwerking van die morele verval in Suid-Afrika, mag dit nooit die enigste rede wees waarom hierdie waarhede met groot ywer verkondig word nie. Die aanvaarding van hierdie geloofswaarhede word deur Petrus in 1:3-4 met 'n hele paar ander sake verbind. Die apostels ontvang nie slegs deur die geloofswaarhede die vermoë om reg te lewe nie, maar dit lei ook daartoe dat hulle die ewige lewe ontvang (vgl. punt 6.2.1). Deur hierdie geloofswaarhede ontvang die gelowige kosbare en die allergrootste beloftes vir die toekoms (vgl. punt 6.2.3) en deur hierdie geloofswaarhede kom die gelowiges in 'n verbondsverhouding met God te staan (vgl. punt 6.2.4). Daar rus dus 'n dure verantwoordelikheid op die gelowiges in Suid-Afrika wat in 'n verbondsverhouding met God staan en self deur die aanvaarde geloofswaarhede seker is van die ewige lewe om hierdie aanvaarde waarhede met groot ywer aan ongelowiges te verkondig. Gelowiges het hierdie verantwoordelikheid juis omdat hulle leef vanuit die hoop dat die heerlike beloftes van Jesus Christus vervul sal word.

\section{Bibliografie}

BALTZER, K. 1971. The covenant formulary in Old Testament, Jewish, and early Christian writings. Philadelphia : Fortress Press.

BARR, J. 1961. The semantics of Biblical language. Oxford : University Press.

BAUCKHAM, R.J. 1983. Jude, 2 Peter. Texas : Waco. (Word Biblical Commentary, vol. 50.)

BIGG, C. 1969. A critical and exegetical commentary on the epistles of St. Peter and St. Jude. Edenburgh : Clark.

BOTHA, J. 1989a. Die Louw \& Nida-Woordeboek: 'n kragtige nuwe hulpmiddel vir die eksegeet, prediker en Bybelvertaler. In die Skriflig, 23(92):1-23, Des.

BOTHA, J. 1989b. 'n Praktiese riglyn vir die gebruik van die Louw \& NidaWoordeboek: geïllustreer aan die hand van die betekenis kaıpós in Galasiërs 6:9-10. In die Skriflig, 23(92):24-39, Des.

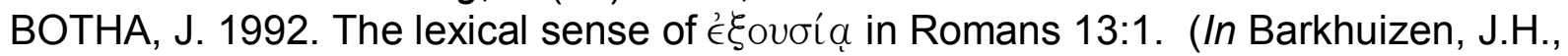
Stander, H.F. \& Swart, G.J., reds. Hupomnema: feesbundel opgedra aan prof. J.P. Louw. Pretoria : Universiteit van Pretoria. p. 33-43.) 
BREED, 1994. Die kenmotief in 2 Petrus: 'n eksegetiese studie. Potchefstroom : PU vir CHO. (Th.D.-proefskrif.)

BROWN, J. 1980. Parting counsels: an exposition of 2 Peter 1. Edinburg : The Banner of Truth Trust. (A Geneva series Commentary.)

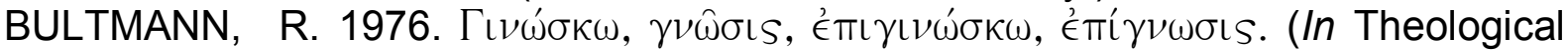
dictionary of the New Testament, 1:689-719.)

BYBEL. 1933. Die Bybel: dit is die ganse Heilige Skrif wat al die kanonieke boeke van die Ou en die Nuwe Testament bevat. Kaapstad: Britse en Buitelandse Bybelgenootskap.

BYBEL. 1983. Die Bybel: nuwe vertaling. Kaapstad : Bybelgenootskap van SuidAfrika.

COETZEE, J.C. 1988. Gedagtestruktuurontleding en die eksegese van die Heilige Skrifte. (In Coetzee, J.C., red. Koninkryk, Gees en Woord. Huldigingsbundel aangebied aan prof. dr. Lambertus Floor by sy emeritaat as professor in die Nuwe Testament aan die Teologiese Skool, Potchefstroom en die Fakulteit Teologie van die Potchefstroomse Universiteit vir Christelike Hoër Onderwys. Pretoria : N.G. Kerkboekhandel. p. 19-37.)

COLLINS, J.J. 1984. Testaments. (In Stone, M.E., ed. Jewish writings of the second temple period: apocrypha, pseudepigrapha, Qumran sectarian writings, Philo, Josephus. Philadelphia : Fortress Press. p. 325-355.)

DANKER, F.W. 1978. 2 Peter: A solemn decree. The Catholic Biblical Quarterly, 40:64-82.

DE JONGE, M. 1991. Jewish eschatology, early Christian christology and the Testaments of the Twelve Patriarchs. Leiden : Brill. (Supplements to Novum Testamentum vol. 63.)

DE WET, G.J. 1998. Morele herstel. Beeld:10, Oktober 26.

DONFRIED, K.P. 1974. The setting of second Clement in early Christianity. Leiden : Brill. 240 p. (Supplements to Novum Testamentum, 33:41-48.)

FORNBERG, T. 1977. An early church in a pluralistic society: a study of 2 Peter. Lund : Carl Bloms Boktryckeri.

FRANKEMÖLLE, H. 1990. 1. Petrusbrief. 2 Petrusbrief. Judasbrief. Würzburg : Echter.

GREIJDANUS, S. 1929. De brieven van de apostelen Petrus en Johannes, en de brief van Judas. Amsterdam : Van Bottenburg. (Kommentaar op het Nieuwe Testament.)

GRUNDMANN, W. 1974. Der Brief des Judas und der zweite Brief des Petrus. Berlin : Evangelische Verlagsanstalt. (Theologischer Handkommentar zum Neuen Testament.)

HIEBERT, D.E. 1989. Second Peter and Jude: an expositional commentary. Greenville : Unusual publications.

HUTHER, J.E. 1867. Kritisch exegetisches Handbuch über den 1. Brief des Petrus, den Brief des Judas und den 2. Brief des Petrus. Göttingen : Vandenhoeck \& Ruprech Verlag.

JORDAAN, G.J.C. 1988. 2 Petrus 1:19, 21 in die lig van gedagtestruktuuranalise. (In Coetzee, J.C., red. Koninkryk, Gees en Woord. Huldigingsbundel aangebied aan prof. dr. Lambertus Floor by sy emeritaat as professor in die Nuwe Testament aan die Teologiese Skool, Potchefstroom en die Fakulteit Teologie van die Potchefstroomse Universiteit vir Christelike Hoër Onderwys. Pretoria : N.G. Kerkboekhandel. p. 70-80.) 
KAHMANN, J.J.A. 1983. De tweede brief van Petrus. Vertaald en toegelicht door prof. dr. J.J.A. Kahmann. (In Kahmann, J.J.A. \& Dehandschutter, B. De tweede brief van Petrus. Vertaald en toegelicht door prof. dr. J.J.A. Kahmann. De brief van Judas. Vertaald en toegelicht door dr. B. Dehandschutter. Boxtel : Katholieke Bijbelstichting. p. 11-112.)

KELLY, J.N.D. 1969. A commentary on the epistles of Peter and of Jude. London : Adam \& Charles Black.

KNIGHT, J. 1995. 2 Peter and Jude. Sheffield : Sheffield Academic Press.

$\mathrm{KNOCH}$, O. 1990. Der erste und zweite Petrusbrief. Der Judasbrief. Regensburg : Friedrich Pustet. 333 p. (Regensburger Neues Testament.)

KOLENKOW, A.B. 1975. The genre testament and forecasts of the future in the Hellenistic Jewish milieu. Journal for the study of Judaism in the Persian, Hellenistic and Roman period, 6(1):57-71.

KOLENKOW, A.B. 1986. The literary genre "Testament". (In Kraft, A. \& Nickelsburg, G.W.E., eds. Early Judaism and its modern interpreters. Georgia : Scholars Press. p. 259-267.)

KURZ, W.S. 1990. Farewell addresses in the New Testament. Collegeville : The Liturgical Press.

LANE, W.L. 1975. The Gospel according to Mark. Grand Rapids : Eerdmans. (The New International Commentary on the New Testament.)

LOUW, J.P. \& NIDA, E.A. 1988a. Greek-English lexicon of the New Testament based on semantic domains. (Vol. 1.) New York : United Bible Societies.

LOUW, J.P. \& NIDA, E.A. 1988b. Greek-English lexicon of the New Testament based on semantic domains. (Vol. 2.) New York : United Bible Societies.

LYONS, J. 1978. Semantics. (Vol. 1.) Cambridge : University Press.

MBEKI, T. 1998. Toespraak gelewer tydens 'n spitsberaad op 10 November. Kaapstad. (Ongepubliseer.)

MÜLLER, J.J. 1974. Nuwe-Testamentiese apokriewe. Pretoria : N.G. Kerk-Uitgewers.

NIDA, E.A. 1972. Implications of contemporary linguistics for biblical scholarship. Journal of Biblical Literature, 91:73-89.

NIDA, E.A. \& LOUW, J.P. 1992. Lexical semantics of the Greek New Testament: a supplement to the Greek-English lexicon of the New Testament based on semantic domains. Atlanta : Scholars Press. (Society of Biblical Literature.)

OTTO, K. 1967. Der zweite Petrusbrief. Düsseldorf : Patmos-Verlag.

PAULSEN, H. 1992. Der zweite Petrusbrief und der Judasbrief. Göttingen : Vandenhoeck \& Ruprecht. (Kritisch-exegetischer Kommentar über das Neue Testament.)

PICIRELLI, R.E. 1975. The meaning of "Epignosis". The Evangelical Quarterly, 47:85-93.

PICIRILLI, R.E. 1963. An exegesis of the Greek text of second Peter, chapters one and two. Greenville : Bob Jones University. (D.Phil. Thesis.)

REICKE, B. 1982. The epistle of James, Peter, and Jude. Garden City : Doubleday \& Company.

SCHELKLE, K.H. 1988. Die Petrusbriefe. Der Judasbrief. Freiburg : Herder. (Herders Theologischer Kommentar zum Neuen Testament.)

SILVA, M. 1983. Biblical words and their meaning: an introduction to lexical semantics. Grand Rapids : Zondervan.

STAUFFER, E. 1948. Die Theologie des Neuen Testaments. Gütersloh : Bertelsmann. RAC 1 (1950) Sp29-35; Die Theologie des Neuen Testaments (Stuttgart 1940), S 327-30. 
THISELTON, A.C. 1979. Semantics and New Testament interpretation. (In Marshall, I.H., ed. New Testament interpretation: essays on principles and methods. Cape Town : Oxford University Press. p. 75-104.)

VAN GORP, H. 1984. Lexikon van literaire termen. Leuven : Wolters.

VAN HOUWELINGEN, P.H.R. 1988. De tweede trompet: de authenticiteit van de tweede brief van Petrus. Kampen : Kok. (Proefschrift - Theologische Universiteit van de Gereformeerde Kerken in Nederland te Kampen.)

VAN HOUWELINGEN, P.H.R. 1993. 2 Petrus en Judas: testament in tweevoud. Kampen : Kok. (Commentaar op het Nieuwe Testament.)

VAN RENSBURG, J.J.J. 1992. Vreemdelingskap in 1 Petrus: Voorlopige definiëring van die betekenis van die betrokke Griekse woorde. (In Barkhuizen, J.H., Stander, H.F., Swart, G.J., reds. Hupomnema. Feesbundel opgedra aan prof. J.P. Louw. Pretoria : Universiteit van Pretoria. p. 283-306.)

VÖGTLE, A. 1972. Die Schriftwerdung der apostolischen Paradosis nach 2. Petr. 1,12-15. (In Neues Testament und Geschichte: historisches Geschehen und Deutung im Neuen Testament. Tübingen : Mohr. p. 297-305.)

WOLTERS, A. 1990. "Partners of the deity": a covenantal reading of 2 Peter 1:4. Calvin Theological Journal, 25(1):28-44, Apr.

\section{Kernbegrippe:}

2 Petrus

geloofswaarhede

kennis

morele verval

testamentgenre

verbondsverhouding

Key concepts:

2 Peter

covenantal relationship

knowledge

moral corruption

religious truths

testament genre 